\title{
Att orientera sig i skolan, staden och svenskheten. Det fria skolvalet enligt elever i förorten
}

\author{
Majsa Allelin
}

SAMMANDRAG: Under 1990-talet implementerades genomgripande omstruktureringar av det svenska utbildningsväsendet. Bland annat genomfördes en friskolereform vars konsekvenser än i dag diskuteras i den politiska debatten. I debattens skugga fortsätter allt fler elever att söka sig till fristående skolor. Vad innebär detta för möjligheterna till en likvärdig skola för alla och för den segregation som präglar våra storstäder? I Majsa Allelins artikel står eleverna och deras valsituation i centrum. Vi möter elever från en rasifierad svensk förort där en del valt att byta till en fristående skola i innerstaden, och en del valt att gå kvar i kommunala skolor i hemområdet. Utifrån elevernas motiv till och erfarenheter av valen visar studien på att de sociala och ekonomiska villkor som råder $\mathrm{i}$ staden samspelar med skolornas organisatoriska och pedagogiska förutsättningar, vilket, för elevernas del, bidrar till en reproduktion av segregationen. För eleverna får "svenskhet" representera den vedertagna definitionen av att ha lyckats och det är utifrån detta begrepp som de navigerar på utbildningsmarknaden och därmed i staden.

NYCKELORD: utbildningsmarknad; det fria skolvalet; segregation; svenskhet; förortsskolor; friskolor.

PUBLICERINGSHISTORIK: Originalpublicering.

MAJSA ALLELIN är doktorand i socialt arbete vid Göteborgs universitet.

E-POSTADRESS: majsa.allelin@socwork.gu.se

FÖRSLAG PÅ KÄLLANGIVELSE:

Allelin, Majsa (20I5) "Att orientera sig i skolan, staden och svenskheten. Det fria skolvalet enligt elever i förorten", i Arkiv. Tidskrift för samhällsanalys, nr 4, s. 69-98. DOI: http://dx.doi.org/IO.I3068/2000-6217.4.2

(C) Majsa Allelin/Arkiv förlag \& tidskrift 2015 (publicerad I8 november 20I5)

Artikeln distribueras enligt en upphovsrättslicens från Creative Commons: Erkännande-Ickekommersiell-IngaBearbetningar 3.0 Unported, som medger fri ickekommersiell användning och spridning i oförändrat skick så länge källan anges. 
Arkiv. Tidskrift för samhällsanalys är en sakkunniggranskad vetenskaplig tidskrift för samhällsvetenskap och historia. Samtliga artiklar publiceras fritt tillgängliga på:

www.tidskriftenarkiv.se

(beständig länk, DoI: http://dx.doi.org/IO.I3068/2000-62I7)

Den här artikeln finns tillgänglig i följande format:

PDF \& HTML: via beständig länk, DOI: http://dx.doi.org/IO.I3068/2000-6217.4.2 EPUB: ingår i e-boksutgåva av numret, ISBN: 978 9I 79242725

TRYCK: ingår i bokutgåva av numret, ISBN: 978 9I 79242732

Grafisk utformning och sidnumrering är identisk i pdf och tryck.

Samtliga artiklar i nr 4 (2015) nås via beständig länk, DOI: http://dx.doi.org/IO.I3068/2000-6217.4

Arkiv. Tidskrift för sambällsanalys ISSN: 2000-62I7 (för elektronisk resurs)

ISSN: 2000-6225 (för tryckta nummer)

ges ut av

Stiftelsen Arkiv för främjande och spridning av samhällsvetenskaplig och historisk forskning

genom

Arkiv förlag \& tidskrift

Box 1559

SE-22I OI Lund

BESÖк: L Gråbrödersg $3 \mathrm{c}$, ipg

TEL: O46-I3 3920

ARKIV FÖRLAG: arkiv@arkiv.nu·www.arkiv.nu

TIDSKRIFTEN ARKIV: red@tidskriftenarkiv.se · www.tidskriftenarkiv.se

ANSVARIg UTGIVARE \& CHEFREDAKTÖR: Sven Hort

ADMINistrativ RedAKTÖr: David Lindberg

RedAKtörer: Paavo Bergman, Lisa Kings, Zhanna Kravchenko 


\title{
Att orientera sig i skolan, staden och svenskheten. Det fria skolvalet enligt elever i förorten
}

\author{
MAJSA ALLELIN
}

\section{Inledning}

Det fria skolvalet är en självklarhet för många i dagens Sverige. I storstäderna har fristående skolor blivit ett givet alternativ till de kommunala. I Sveriges tre största städer går mellan var tredje och var sjätte elev

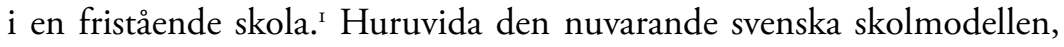
som präglas av decentralisering, marknadslogiska modeller och ansvarsförskjutning från det offentliga till det privata, gynnar eleverna råder det däremot skilda uppfattningar om.

Med anledning av den konkurrensrelation som råder skolor emellan kan konstateras att vi har fått "vinnarskolor" och "förlorarskolor" (Kallstenius 20IO), i en process där förortsskolor ofta utkonkurreras av innerstadsskolor (Sernhede 20II). Omstruktureringarna ställer således på nytt frågan om utbildningsväsendets samhälleliga roll och utmanar idén om skolan som samhällsfostrande (Englund 1995). Vidare omförhandlar reformerna elevens roll och ansvar i utbildningssystemet, bland annat genom att eleven framställs som "väljare" (Fredriksson 20I0; jfr även Liedman 20II).

I. Stockholm 30 procent, Göteborg 28 procent och Malmö I5 procent. Uppgifterna gäller läsåret 20I4/20I5 och är hämtade från Skolverkets databas SIRIS (Skolverkets Internetbaserade Resultat- och kvalitetsInformationsSystem), http://siris.skolverket.se/ siris/ris.elever_gr.rapport, hämtat 20 juni 2014. 
Den här artikeln knyter an till utbildningssociologisk forskning och avser bidra med ett elevperspektiv. Kontexten är den etniska och klassmässiga storstadssegregation som "det fria skolvalet" verkar i, eftersom det främst är i storstäderna som det finns en hög skoletablering och det är där konkurrensen är som tydligast (Skolverket 2005). Artikeln bygger på en studie av hur elever som bor i en rasifierad förort orienterar sig på utbildningsmarknaden. Vissa har valt att gå i en fristående skola $\mathrm{i}$ innerstaden, medan andra har valt att gå kvar i en kommunal förortsskola i hemområdet. Syftet är att kritiskt diskutera det fria skolvalet genom att belysa elevernas motiv till, resonemang kring och erfarenheter av valet. Vidare diskuterar artikeln de reproduktiva processer som äger rum genom skolan, liksom de potentiellt transformativa möjligheterna som kan uppstå i en rasifierad arbetarposition, utifrån ett individ- och samhällsperspektiv. Studien ska läsas som ett utsnitt ur den vardag som eleverna upplever.

Följande frågeställningar är därför vägledande:

- Varför väljer vissa elever i en förort att gå på en fristående skola i centrum?

- Varför väljer andra elever i samma förort att gå kvar i den kommunala skolan i upptagningsområdet?

- Hur har dessa skolval och skolformer upplevts av eleverna?

\section{Disposition}

Artikeln börjar med en bakgrundsbeskrivning av dagens skolpolitik. För att synliggöra hur utbildningsmarknaden påverkar relationerna i skolan diskuteras också stadens etniska och klassmässiga struktur, något som ska ses som en kontext som utbildningsmarknaden verkar i och villkoras av. Genomgången av tidigare forskning följs av centrala teoretiska begrepp, som fångar de mekanismer för reproduktion som skolan bidrar till att befästa. Därefter följer en presentation av den empiriska studiens metodologi och metod. Analysen bygger på djupintervjuer med totalt tolv elever om deras skolval. Den avslutas med en sammanfattande diskussion av de huvudsakliga slutsatserna. 


\section{Etableringen av en utbildningsmarknad}

År I991 gjorde dåvarande regering en genomgripande omstrukturering av skolpolitiken, som innebar att kommunen i stället för staten fick ansvar för skolan i bland annat budget- och anställningsfrågor. En huvudsaklig avsikt med denna form av decentralisering var att makten skulle komma närmare invånarna, för att på så sätt öka det lokala deltagandet. Kommunerna ansågs också veta bäst vilka förbättringar som krävdes och hur de effektivast skulle utformas (Skolverket 1996). Samtidigt har kommunaliseringen lämnat skolan med en större ekonomiskt utsatthet, eftersom kommunerna nu är ansvariga för att fördela tilldelad budget mellan flera skilda verksamheter, så som barnomsorg, kultur och fritid, äldreomsorg, utbildning. Även om skolans innehåll till stor del är statligt reglerad riskerar kommunaliseringen, med andra ord skolans organisering och administrering, att försvåra kravet på en nationellt likvärdig skola (Quennerstedt 20I2).

Decentraliseringsprocesserna har dock inte enbart skett genom en vertikal delegering utan även en horisontell sådan, genom friskolereformen som infördes året därpå - ett förslag som förvisso lyftes fram redan under 1980-talet (proposition 1982/83:I). Den vertikala delegeringen gjorde det möjligt för andra aktörer än de offentliga, så som privata bolag, entreprenörer, stiftelser och religiösa samfund, att stå som huvudmän för skolor. Den borgerliga regeringens förslag att låta privata aktörer starta skolor och införa en konkurrenssituation skolor emellan trädde i kraft med avsikt att ge hushållen själva möjlighet att bestämma vilken utbildning barnen skulle få och minska bundenheten till den skola man bodde närmast. Genom skolprofilering och skolval är det tänkt att friskolereformen och konkurrensen ska skapa mångfald och öka kvaliteten i undervisningen (Skolverket I996, s. II; Skolverket 2003). För att skapa god konkurrens har fristående skolor fått andra ekonomiska förutsättningar (som möjligheten att bli sponsrad med material av andra företag) och krav än de kommunala skolorna, vilket också gör att de har mer makt över sin egen budget och större frihet att utforma undervisningen och elevrekryteringen.

Från att skolan har haft en uttalad roll som medborgarfostrande syftar den i dag alltmer till att vara individuellt främjande (Dovemark 
2004); det kan benämnas i termer av en förskjutning från public good till private good (Englund 1993). Ansvarsförskjutningen, av både styrningen av skolan och själva skolvalet, har dock visat sig få negativa konskevenser för elever som behöver extra stöd eller saknar motivation eller kunskap om hur man orienterar sig i skolan och på utbildningsmarknaden (jfr Bourdieu \& Passeron 2008; Sernhede 20II).

\section{Förortsskolor och innerstadskolor - en ny form av parallellskola?}

Utbildningssystemets sortering av elever är ingen ny effekt, men förutsättningarna för social reproduktion gör att den sker på delvis nya sätt och i vissa avseenden verkar den också starkare. Forskning visar att många skolor i socioekonomiskt utsatta områden har hamnat i en ond spiral där elever som kommer från hushåll med högre utbildningsbakgrund eller som har goda studievanor flyttar till attraktivare skolor i andra områden, till exempel innerstaden (Skolverket 1996; Skolverket 2003).

Enligt skolforskaren Jenny Kallstenius nyttjas valfriheten som mest självständigt av en urban medelklass (Kallstenius 20ı0; Ball 2006; Bunar 2009, s. 91; Runfors 2003, s. 205). Det leder ofta till att skolan i förorten får mindre resurser och en högre andel elever som behöver extra stöd (bl.a. Sernhede 20II; Ungdomsstyrelsen 2008; Bunar \& Kallstenius 2008; Dahlstedt 2007; Skolverket 2003, s. 19). Parallellt med denna utveckling visar siffror att klyftan mellan elever som når respektive inte når målen blir allt större och att det sammanfaller med stadens segregationsmönster (Skolverket 20IIa; Molina 1997).

Förutom nyttjandet av skolvalet finns det klassmässiga och etniska mönster vad gäller uppnådda kunskapsmål. Elever med utländsk bakgrund $^{2}$ tenderar att i samtliga obligatoriska ämnen i lägre grad nå kriterierna för godkända betyg (Skolverket 20IIa; Skolverket 20I2, s. 56). Det finns dock stora variationer inom gruppen och bryter man ned elevgrupperna efter världsdel visar det sig att elever med nordiskt eller nord-

2. Skolverkets definition: elever som är födda utomlands samt elever födda i Sverige vars båda föräldrar är födda utomlands (http://salsa.artisan.se/definitioner.htm, hämtat 20 juni 20I4). 
amerikanskt ursprung har betydligt högre genomsnittligt meritvärde än elever från exempelvis Afrika (Skolverket 20ıгa). Det sammanfaller med segregationens andra områden, så som på bostads- och arbetsmarknaden (Magnusson Turner 200I; Sernhede 20II; Molina 1997; Smith 1989). En förklaring är att det ofta saknas kunskaper och erfarenheter i "ryggsäcken" som värderas eller anses behövas för att man ska kunna orientera sig i skolan, exempelvis gällande läxor och utvecklingssamtal. En annan möjlig förklaring, som också baserar sig på idén om sämre ingångsvärden, är att skolor i mångetniska områden har betydligt fler elever som börjar i den svenska skolan efter vanlig skolstartsålder, vilket gör att de kommer vara äldre innan de har lärt känna skolsystemet och sakna försprång i det svenska språket (Runfors 2003, s. I42-I45).

Skolverket lyfter fram två möjliga förklaringar till att skillnaderna i resultat mellan olika elevgrupper har ökat de senaste åren. Dels kan det bero på att det skett en ökad spridning av utbildningskvaliteten skolor emellan, dels att elever i större utsträckning "sorteras till olika skolor efter sina förutsättningar att prestera goda studieresultat" (Skolverket 2012, s. 58). I denna elevsortering är förortsskolorna de som drabbats hårdast. Kombinationen av elevsammansättningen, som karaktäriseras av en hög andel elever med utländsk bakgrund och som oftare har en mindre fördelaktig socioekonomisk situation, och den ökande tendensen för elever att flytta från och inte till skolan, gör att skolorna i förorten i många fall står med mindre pengar, mer resurskrävande elever och sämre rykte.

I Göteborg år 20I3 låg den skola med lägst andel elever som klarade de nationella kunskapsmålen på I8 procent medan skolan med högst andel låg på 96 procent (rikssnittet var 76 procent). ${ }^{3}$ När det skapas en sådan prestationsmässig segregation missar eleverna i bortvalsskolorna den "kamrateffekt" som innebär att elevers skolprestationer påverkas av klasskamraterna och skolans sociala miljö. Ju fler högutbildade föräldrar till elever som finns i en skolklass, desto mer sannolikt är det att elever till lågutbildade föräldrar förbättrar sina prestationer (Dahlstedt 2007, s. 30; Bunar 2005, s. 82; Härnqvist 1994, s. 133). Att söka sig till en annan skola kan därför tolkas som att man väljer en annan elevsammansättning, kamrateffekt

3. Från Skolverkets databas SALSA (Skolverkets Arbetsverktyg för Lokala SambandsAnalyser), http://salsa.artisan.se, hämtat 20 juni 2014. 
och social klass. I Stockholm har Kallstenius (20IO) märkt ett mönster: när elever från förorten söker sig till de kommunala skolorna i innerstaden söker sig de befintliga eleverna i sin tur bort från dessa och till de fristående skolorna i innerstaden. Skolbytena får en tydlig social dimension snarare än en pedagogisk sådan, och de är hierarkiskt ordnade. Fristående innerstadsskolor framstår som det attraktivaste alternativet, som eleverna söker sig till, medan de kommunala skolorna i förorten framställs som sämre skolor, som elever söker sig från. Det är med andra ord den specifika elevsammansättningen som är avgörande för skolvalet.

Konkurrensen mellan skolorna gör att vissa tvingas lägga ned. 20II lades 66 stycken kommunala skolor ned samtidigt som antalet fristående ökade med 32 stycken (Skolverket 20Irb). För att förbli attraktiv är marknadsföringen väsentlig. Detta gör att många lärare måste förhålla sig till skolan som dess ansikte utåt. Studier har också visat att lärarna på vinstdrivande friskolor generellt sett har en mer uttalad "marknadsanda” än lärare på kommunala skolor och i större utsträckning intar ett förhållningssätt med beteenden och attityder gentemot eleven som kund (Fredriksson 20Io, s. I80-I8I). Samtidigt uppges lärarna i mångetniska kommunala skolor i stället känna en stark uppgivenhet när dessa tvingas konkurrera med "vita" skolor och blir till bortvalsskolor (Bunar 2009, s. I27). Uppgivenheten kan tolkas som ett uttryck för maktlösheten man upplever när man i sin yrkesposition känner sig systematiskt bortvald.

\section{Selektionen i skolan och symboliskt kapital}

När skolans ökade autonomi bidrar till social reproduktion gör den det genom en osynlig sortering som omvandlar "objektiva" företeelser, så som betygsättning och åtskillnader mellan elever och lärare, till rationella utbildningslogiker som framställs som naturliga. Genom att utbildningssystemet uppvisar sig som objektivt och tekniskt döljer den och legitimerar på så sätt reproduktionen av klass och etnisk diskriminering (Bourdieu \& Passeron 2008, s. I54-I55, 202).

Förutom den dolda tekniska selektionen, exempelvis genom utformningen av prov och betyg, är det symboliska kapitalet centralt för elevers skolgång. Till stora delar kan skolan beskrivas som en språklig verksam- 
het och enligt det "kommunikativa system" som Bourdieu menar att skolan kan uppfattas som utgör språkligt kapital i kombination med selektionsgrad - alltså på vilken nivå och hur klassinterna kraven är för att få godkänt - de faktorer som påverkar elevernas förutsättningar för att ta in de budskap som skolan sänder ut (Bourdieu \& Passeron 2008, s. 135, I55). Det språkliga kapitalet är därför väsentligt för eleven, eftersom det fungerar som kriterium vid selektionen (Bourdieu \& Passeron 2008, s. I63-164). I en etniskt och klassbundet segregerad stad framstår därför "förortssvenskan" som en sämre svenska än den som ingår i skolans vedertagna språkbruk.

Vidare påverkar det språkliga kapitalet elevers självuppfattning. Den bildade klassen har en självsäkerhet och självklarhet som erkänns och bekräftas kontinuerligt i den akademiska miljön, medan elever från arbetarklassen i stället tenderar att svara med själveliminering i form av till exempel avhopp från studier innan en formell sållning i form av examination ens skett (Bourdieu \& Passeron 2008, s. 202). Det gör både att skolorna slipper stå som ansvariga för elimineringen, och att utbildningsväsendet misslyckas med att leva upp till den meritokratiska idén. Familjers strategier tillsammans med utbildningens specifika logik skapar således förutsättningar för social reproduktion (Bourdieu 2004, s. 3I).

\section{Subjektspositioner och (dis)identifikation}

Även andra kulturella praktiker än språket kan fungera som markörer för att skapa distinktion och (dis)identifikation. Beverley Skeggs (1997) menar att en anledning till att arbetarklassen i vissa fall tenderar att vilja disidentifiera sig med sin egen klass är att "arbetarklass" uppfattas som synonymt med något smutsigt, farligt eller odugligt (liknande värderande benämningar kan vara "white trash" eller "blatte"). Strategin att sträva efter respektabilitet och erkännande genom kunskap eller en föreställning om hur man ska tala, klä sig och bete sig för att upphöja sin klassposition kan i vissa fall generera en klassresa och är ett sätt att få respekt (Skeggs 1997, s. I19, I32, 138).

Med klasstillhörighet kommer olika subjektspositioner, vilkas innebörd är beroende av kontext och påverkade av exempelvis könstillhörig- 
het, var man bor, ålder och så vidare. Inom en klass finns alltså en heterogenitet som kan hjälpa oss att nyansera och stratifiera villkoren för olika grupper. Subjektspositionerna fylls med karaktärsdefinitioner som kan stå i förhållande till den andra antingen genom identifikation med dem man känner samhörighet med eller genom ett definierande av vad man inte är (Skeggs 1997, s. 98). På så sätt står klasstillhörigheten förstås i relation till andra villkorande förutsättningar och placeras i en historiskt specifik kontext.

När vi diskuterar elever i förorten respektive i innerstaden talar vi därmed också om olika subjektspositioner. Eleverna förhåller sig till olika karaktärsdefinitioner som de tillskrivs och som de delvis internaliserar utifrån klass, boende, etnisk bakgrund och ålder. Internaliseringen kan innebära meningsskapande processer av såväl identifikation som disidentifikation genom praktiker och normer baserade på stereotypiseringar, romantiseringar eller föraktande föreställningar.

\section{I intersektionen: den fysiska och mentala platsens betydelse}

Utöver tillhörigheterna klass och etnicitet är boendet en faktor som kan begränsa eller möjliggöra ens nyttjande av delar av välfärden (särskilt med tanke på att så pass många offentliga verksamheter är förlagda under respektive stadsdels regi) och näringslivet. Det kan också vara en faktor som påverkar ens möjligheter att kunna ta sig in på arbetsmarknaden. Om området man bor i är förknippat med negativa föreställningar kan dessa associationer ligga till grund för diskriminering, såväl i det vardagliga sociala livet som vid mer direkta och materiellt avgörande processer, till exempel i sökandet av arbete och bostad (Smith 1989, s. 44-45; Dikeç 2007).

Det geografiska rummet innefattar således en relationell dimension mellan olika subjekt och rum genom att platser förnims med känslor och minnen, och de omfattar sociala, kulturella och ekonomiska relationer (Harvey 20II, s. 24). I en etniskt och ekonomiskt segregerad stad som Göteborg skapas inte enbart materiella skillnader, genom till exempel ständiga hot om nedläggningar av sociala instanser och hårdare 
bevakning (se Wacquant 2009) platser emellan, utan även åtskillnader på ett mentalt plan. I stadens sociogeografiska hierarki (Franzén 200I, s. 4I) tenderar förorten att behäftas med associationer som något hotfullt och problemfyllt, vilket inte sällan legitimerar en territorialisering av social kontroll (Gilroy I98I, s. 2I4; Dikeç 2007; Wacquant 2009). De stigmatiserande föreställningarna om ungdomen i förorten tränger sig in bland socialarbetare, politiker, poliser, lärare och andra samhällsviktiga personer som jobbar i dessa områden och påverkar det dagliga arbetet och bemötandet (Sernhede 2006, s. I06). Med bristen på erkännande (Franzén 200I) får invånarna på så sätt uppleva att de är andra klassens medborgare, vilket påverkar självuppfattningen hos många av de ungdomar som bor i dessa miljonprogramsområden. Det får allvarliga effekter på bland annat skolan och sysselsättningen (Sernhede 2007; Ålund 1997, s. I4-15). Som motstrategi kan i stället ett slags "stadsdelsnationalism" skapas (Sernhede 2007, s. 176), en gemenskap som bygger på kollektivt erfaren alienation, som samtidigt också riskerar att begränsa invånarnas rörlighet fysiskt och mentalt och på så vis återskapa segregationen.

\section{Intervjuer och urval}

Det huvudsakliga intervjuurvalet utgår från den elevgrupp som tidigare forskning framhåller drabbats hårdast av det fria skolvalet, nämligen elever som bor i förorten (Skolverket 20I2). Både elever som valt att byta till en fristående innerstadsskola och elever som har valt att gå kvar i de kommunala förortsskolorna i upptagningsområdet har intervjuats. Studien bygger på totalt nio inspelade och transkriberade semi-strukturerade intervjuer (Kvale \& Brinkmann 2009) med sammanlagt tolv elever i årskurs 9. Fyra av elevintervjuerna gjordes i par och fyra gjordes enskilt. Två enskilda och två parintervjuer gjordes med elever på en fristående skola i innerstaden, och lika många gjordes med elever på de kommunala skolorna i hemområdet. En gruppintervju har även gjorts med tre lärare på samma fristående skola som den ena elevgruppen går på och en ostrukturerad intervju med en resursanställd på en av förortsskolorna, med avsikten att kontextualisera elevernas situation. Anledningen till att intervjuerna genomfördes med elever på grundskolenivå är att grund- 
skolan är obligatorisk och jämfört med gymnasiet tämligen fri från profilering. På gymnasiet har det dessutom redan gjorts en förhållandevis avgörande samhällssortering.

Den fristående skola som den ena intervjugruppen går på ligger i centrala innerstaden där andelen godkända elever som når kunskapsmålen ligger i linje med rikssnittet. ${ }^{4}$ Skolan kommer här att kallas för Liberum. Det är en skola med en geografisk och etnisk mångfald av elever och på skolans hemsida går även att märka att den avser uppvisa en mångfald av elever vad gäller just etnicitet.' Liberum ingår dessutom i en av Sveriges största skolkoncerner, som är ägare till över Ioo skolor runt om i landet. Denna koncern är i sin tur ägd av ett annat internationellt bolag, som äger cirka 90 företag runt om i världen. Bara i Sverige äger och investerar bolaget bland annat i företagsverksamheter inom turism, infrastruktur och godistillverkning.

Eleverna som valt att gå kvar i hemområdet kommer inte från någon särskild skola, då det inte varit nödvändigt för studiens syfte. Däremot kommer samtliga dessa elever från samma förort, som jag här kallar Ängdalen. Här finns tre kommunala skolor som eleverna i studien går på. Andelen elever som når kunskapsmålen i Ängdalen ligger i snitt på omkring 35 procent. Några av eleverna har bytt till en annan kommunal skola inom samma upptagningsområde under sin högstadieperiod. Det bör tilläggas att de flesta av eleverna som intervjuats i Liberum också kommer ifrån Ängdalen - i Ängdalen verkar det nämligen finnas ett mönster bland de elever som väljer att byta område att just byta till skolan Liberum.

Analysen har utvecklats dialektiskt mellan teori och empiri och den är således av abduktiv karaktär (Alvesson \& Sköldberg 2008, s. 55-56). Den avser att besvara studiens frågeställningar genom att synliggöra hur elevers subjektiva upplevelser och strategier kan förstås mot bakgrund av större sociopolitiska sammanhang: elevernas livsvärldar analyseras i relation både till de enskilda skolornas situation och till de större strukturella kontexter som eleverna liksom skolorna befinner sig i (jfr Archer 2007).

4. Rikssnittet var 77 procent år $201 \mathrm{I}$ (http://salsa.artisan.se, hämtat 20 juni 20I4).

5. På varje bild finns minst en person tillhörande kategorin "synlig minoritet" med. 


\section{Föreställningar om svenskhet bland vinster och besparingar}

Av den etniska och klassbundna segregation som skolorna befinner sig i framkommer att elevernas syn på "bra skolor" står i direkt koppling till föreställningen om en "svensk" skola. Att gå på en "svensk" skola innebär en strategi för dessa elever att få bättre möjligheter i det svenska samhället. Eleverna på Liberum byter därför inte bara skola, de byter också område och uttrycker därmed en önskan om att byta livsförutsättningar. Eftersom det finns elever i Ängdalen som byter mellan de kommunala skolorna, som det också finns skillnader mellan, väljer jag att kalla de elever som går i innerstaden inte för "skolbytande" elever utan för "områdesbytande". Begreppet "områdesbytande" synliggör den rasifierade och ekonomiskt segregerade stadens maktaxlar, som inte kan frånkopplas skolans värld. Trots att de fristående skolorna kan erbjuda profileringar och alternativa inriktningar flyr eleverna "en relation och inte en pedagogisk praktik" för att tala med Bunar och Kallstenius (2008, s. I4 f.). "Svenskhet" kan således tolkas som ett symboliskt kapital som är förknippat med privilegier och sammanfaller med det sociala och geografiska rummet, där vissa platser tillskrivs mer svenska egenskaper än andra (se även Kallstenius 20I0, s. I35).

Samtidigt är det många som väljer att stanna kvar i skolan i hemområdet, för att man önskar vara nära vänner men också för att man känner det som att man är på samma prestationsnivå som sina klasskamrater i hemområdet. Den sociala, geografiska och pedagogiska kontexten gör att man känner sig hemma. Att prata om ett rationellt val vore därför att inte ta hänsyn till elevers olika kontexter och logiker och därmed också eventuella andra värden. "Det fria skolvalet" görs i ett sammanhang av etnisk och ekonomisk segregation och bygger därmed på föreställningar om olika grupper och deras materiella och sociala förutsättningar. Följande avsnitt lyfter fram både elever som bytt till den fristående skolan Liberum för att gå i innerstaden och elever som valt att gå kvar på någon av de kommunala skolorna i Ängdalen.

Eleverna som valt att gå på den fristående skolan i innerstaden, Liberum, framhåller att de haft en föreställning om att de skulle få en bättre 
utbildning i och med bytet och att detta varit deras val. Eleverna menar att det som möjliggjort bytet varit att deras kompisar eller släktingar pratat om eller gått på skolan. De framhåller ibland också att det varit på föräldrarnas initiativ och resonerar som föregående elever att det handlade om att säkra en bättre utbildning. Vad som avgör att det är en "bättre" utbildning på Liberum är enligt eleverna att det är en "svensk" skola, där man lär sig "bra" svenska. Jamal, elev på Liberum, beskriver saken:

JAMAL: Man kan förklara det så här. Skolan ligger i stan och om man tänker stan: fint ställe, fina människor som gillar att plugga. Om du tänker förorten ... Vi har till exempel invandrare som precis flyttat, dom börjar i den skolan i närheten. I min förra skola var det 20 procent som knappt kunde svenska.

Användningen av begreppet "svensk" kan tolkas som en referens och är ett sätt för eleverna att beskriva normen i olika situationer och kontexter. När eleverna använder "svensk" som synonymt med "bra skola" är det därför inte nödvändigtvis en personlig åsikt. Det är vad de uppfattar som en vedertagen föreställning och den är fylld med alla de maktrelationer som ingår i segregationsproblematiken, där etnicitet och klass korsar varandra.

Eleverna söker efter "svenskhet" på Liberum men det finns en paradox, nämligen vikten av att ha vänner från Ängdalen i den nya skolan. Lärarna som intervjuades visste inte hur det kom sig att så många från just Ängdalen sökt sig till Liberum. De förklarade att det inneburit ökade kostnader för skolan, som blivit tvungen att satsa på lärare i svenska som andraspråk och hemspråkslärare. Lärarna menade också att en stor grupp - ospecificerat vilken - i dagsläget hade svårt att klara av att ta det egna ansvar som de menade krävdes för att klara sig bra på Liberum. Detta bekräftades också sedan av de intervjuade eleverna. Att inte "kunna" ta eget ansvar som elev blev för skolans del inte bara synonymt med ovana att handskas med denna elevgrupp, det var också en kostnadsfråga, då dessa elever kräver mer resurser i form av extra lärare. Lärarna uppgav att ledningen nu riktat sin marknadsföring mot innerstadsområdena för att få tillbaka de elever som från början sökte till Liberum innan så många från Ängdalen och andra förortsområden började där. Genom skolans aktiva och strategiskt medvetna marknadsfö- 
ring och genom utformningen av verksamheten bidrar skolan på så vis till att reproducera den befintliga skiktningen som präglar staden. Jag frågar eleverna hur det är att gå på Liberum. Taymaz och Yousef, som båda bor i Ängdalen, svarar:

TAYMAZ: Vi får inte tillräckligt med hjälp, vi går inte igenom det vi ska göra, dom har för mycket förväntningar. Vi kommer ifrån en dålig skola i Ängdalen utan lärare, du vet. Så kommer dom [elever från Ängdalen] hit och dom [lärarna] har allt hopp på oss men det fungerar inte så, vi behöver extra lärare.

MAJSA: Hur tycker ni det ska vara?

TAYMAZ: Dom ska hjälpa oss mycket mer, dom borde se vad vi kan.

YOUSEF: Alltså som han sa, dom har för stora förhoppningar på oss. Vi kommer från en bakgrund där man inte är van vid MVG och sånt, vi är vana vid G. Så ger dom oss läxor som högskoleelever kan ha. Det är inte det att vi är dumma eller nåt sånt men det är för stora förväntningar på oss.

MAJSA: Hur klarar dom andra i klassen det då?

TAYMAZ: Dom är födda med svenska bakgrunder och förebilder.

YOUSEF: Dom är vana vid att få hjälp. I vår förra skola fick vi inte sån hjälp.

TAYMAZ: Dom kommer från bättre skolor och rikare familjer, så ... deras föräldrar ...

YOUSEF: Dom lär sig i tidig ålder. Vi kommer inte från samma bakgrund som dom, det är inte som att vi pluggade i tidig ålder, vi var ute och så. Dom gjorde sina läxor och så när dom var små.

MAJSA: Hade ni några förväntningar när ni började här?

TAYMAZ: Jag trodde jag skulle bli riktigt smart, eller jag är smart, men jag trodde jag skulle bli ännu smartare, en av dom smartaste i skolan. Men det blev inte så.

Eleverna menar att kraven som ställs inte är rimliga och att det inte tas hänsyn till deras bakgrund. Upplevelserna Taymaz beskriver ligger i linje med de argument som lärare lyfter fram ur uppgivenhetens logik: att eleverna inte kommer kunna klara sig i den nya "svenska" miljön. Att vara svensk kopplas, av lärare och av elever, intimt till förmågan att kunna hantera kraven i skolan, få hjälp hemifrån, ha förebilder och tidigt förberedas inför den befintliga miljön, med andra ord besitta det utbildningskapital och kulturella kapital som är nödvändigt för att kunna orientera sig i den svenska skolan (Runfors 2003). Denna miljö framträder därför som mer självklar för vissa elever än för andra och tron på att den nya skolan och miljön ska möjliggöra utveckling och prestationsförbättring 
förbyts till besvikelse och distansering. Denna avsaknand av erkännande och bekräftelse kan ta sig flera uttryck, som att eleverna struntar i skolan, eller själveliminering (Bourdieu \& Passeron 2008, s. 202).

Saira och Samira, två elever på Liberum som också bor i Ängdalen, beskriver det så här:

SAIRA: Man får inte ens fråga när man inte förstår. Ibland förstår jag inte så frågar jag inte.

MAJSA: Varför?

SAIRA: Vet inte, det känns så ... vad ska dom tro om mig? Dom kommer tro att jag är dum.

SAMIRA: Som att man är trög, om en lärare förklarat två gånger och man inte fattar tror dom att man är trög.

Elever som valt att stanna kvar i förorten uppger i stället att de oroar sig för att inte få tillräckligt med kunskap och för att få bra betyg för lätt, något som överensstämmer med de områdesbytande elevernas resonemang.

ABED (stannat kvar i Ängdalen): Typ, om du jämför 320 poäng i skolorna i Ängdalen är det typ I20 poäng i en skola inne i stan. Förstår du vad jag menar? [...] Jag tror jag hade fătt mer kunskap [i skolan i stan].

TAYMAZ (bytt till Liberum): Alltså, dom hade typ inga krav på oss där, vad dom ville var att vi skulle vara på lektionerna i alla fall, lära oss lite så fick vi bra betyg. Alla kompisar som jag känner som går där, dom är inte smarta men dom har maxbetyg.

Eleverna gör en tydlig åtskillnad mellan kunskap och betyg. De menar att det krävs olika mycket kunskap på olika skolor för att få samma betyg. På Liberum upplevs det som svårt att få bra betyg, medan det i Ängdalen verkar för lätt. Detta gör att Liberum framställs som en "bättre" skola, där man måste prestera högt. Problematiken är dock som Ailin, en elev som provat att gå på en fristående skola i innerstaden men som valt att gå tillbaka till en skola i Ängdalen, uttrycker det: "Vi är vana vid det som är här, ifall man börjar från ettan så blir man van där." Mötet med den nya skolan blir därför påfrestande och vissa av eleverna väljer i stället att gå tillbaka till skolan i hemområdet.

Utifrån liberala hegemoniska diskurser har eleverna fått höra och lära sig att de kan bli vad de vill och att det är fritt att välja, men när 
de närmar sig realiserandet av denna tro brottas de med upplevelser av exkludering och annorlundahet. Att söka sig till en "bättre" skola resulterar därför inte per automatik i att man blir en "bättre" elev, något som de kanske hade hoppats på. Det räcker inte att bara befinna sig på den rätta platsen eller i den rätta miljön, man måste också ha de rätta "livskunskaperna” (jfr Runfors 2003). På ett individuellt plan må skolbytet verka vara ett logiskt sätt att byta livsförutsättningar, men när resterande vardagsstruktur och ens bakgrund systematiskt gör sig påmind blir det märkbart att strukturella ojämlikheter behöver mer än individuella punktinsatser för att lösas.

I Ängdalen uppger de intervjuade eleverna att de känner det som att de är på samma nivå som de övriga eleverna på skolorna. Denna känsla kan man tolka dels som att den uppstår på grund av det som eleverna själva framhåller mer explicit, alltså att de prestations- och motivationsmässigt befinner sig i nivå med de andra eleverna, dels som att det uppstår mer implicit i känslan av att höra samman med de andra i Ängdalen på grund av gemenskapen kring icke-svenskhet, bostadsområde, språkbruk och så vidare.

Trots explicita och implicita samhörighetskänslor på skolan i Ängdalen uppger de, precis som Liberumeleverna, att de saknar hjälp och förståelse från lärarna. De menar att lärarna har en förutfattad inställning om hur mottagliga och lyssnande de är under lektionerna. Eleverna framhåller att lärarna inte förklarar ordentligt, suddar ut för snabbt från tavlan och inte ger rätt information inför proven samtidigt som de skyller på att eleverna inte lyssnar. Detta skapar en osäker relation gentemot lärarna och en rädsla för att framstå som dum och obegåvad. Aram, som går på en av skolorna i Ängdalen, berättar hur han fått svaret "knäck koden" när han bett en lärare om hjälp. Han menar att svar som dessa gör att man inte ser någon mening med att fortsätta fråga. Att lärarna uppfattas som distanserade och oengagerade påverkar elevernas motivation och självförtroende. Det kan tolkas som att den föreställning som finns om förorten som problemfylld och misslyckad resulterar i en omedveten elevstigmatisering.

Förutom att det handlar om lärarnas förväntningar på och inställning gentemot eleverna från förorten är det en resursfråga. Både på Liberum 
och skolorna i Ängdalen sparas det, men utifrån olika utgångspunkter. Liberum, som har formen av ett aktiebolag, har krav på vinst medan det i Ängdalens skolor, som är kommunala, handlar om att disponera de resurser som finns att tillgå på effektivast möjliga sätt. Det är åter viktigt att komma ihåg att de båda skolformerna står i direkt relation till varandra: den enas förlust av elever gynnar den andra. När en elev från Ängdalen väljer att gå inne i stan på Liberum är det en skolpeng och en eventuellt motiverad elev som försvinner.

I denna konkurrenssituation blir budgethållning och organisatorisk effektivitet centrala direktiv. Denna kostnadseffektivisering kan se ut på olika sätt, men gör sig mer lätthanterlig och kalkylerbar genom olika former av dokumentation som i vissa fall kan övergå till kontrollincitament. Det genererar i sin tur en förskjutning av ansvaret till eleven för anpassning och disciplinering. I en tid när skolornas ekonomiska situation är av central betydelse för verksamhetens fortgång grundar sig därför kontrollen inte lika mycket på en moraliserande grund som på frågan om budgeten. På den skola som Aram, Cindy och Ailin går på i Ängdalen tog sig detta uttryck på ett sätt utöver det vanliga: de fick ett kameraövervakningssystem, med argumentet att det var för stökigt på skolan. Eleverna menar att det dock inte har hjälpt. När jag frågar dem hur det känns med kamerorna svarar de:

CINDY: Dåligt ...

AILIN: Först kändes det som att vi inte kunde göra nånting men nu bryr jag mig inte, jag vet att dom inte tittar på kamerorna. Dom gör det bara för att skrämma oss. Det har hänt bråk och så men dom har inte löst det, kamerorna finns och dom har inte löst det. Så det betyder att dom inte tittar på dom. Dom vill bara skrämma oss.

CINDY: Slösa pengar.

På Liberum dokumenteras i stället eleverna genom att varje försenad minut bokförs i ett datorsystem och adderas ihop under hela skoltiden. Dessa minuter har föräldrarna tillgång till och de får kontinuerliga uppdateringar genom sms och utvecklingssamtal. ${ }^{6}$ Föräldrar och elever på båda skolorna förväntas ta en aktiv roll och reagera på informationen,

6. Till saken hör att olovlig frånvaro eller skolk enligt skollagen (SFS 20I0:80o) ska skrivas in i betyget. 
något som de intervjuade eleverna inte känner igen sig i. Det må få somliga elever och föräldrar, tillfälligt eller långsiktigt, att ta ansvar men för många av de intervjuade eleverna faller den behavioristiska logiken och i stället formas ett habitus av dåligt självförtroende för att de systematiskt blir kontrollerade och dokumenterade och får svart på vitt att de är bristfälliga utan att de får vidare stöd. Det försämrade självförtroendet kan i värsta fall resultera i själveliminering genom att eleverna inte vågar eller ser någon mening med att ställa frågor eller ta plats.

Diskrepansen mellan en nationellt likvärdig skola, "en skola för alla", och elevers olika förutsättningar var tänkt att upplösas genom friskolereformen, "ett skolval för alla". Men inte heller denna reform verkar kunna tillgodose elevers särskilda behov av stöd. Med en verksamhet som har krav på vinst och en elevrörlighet som är baserad på etniska föreställningar i en segregerad stad verkar det som att situationen är oförändrad för de elever som redan hamnat utanför.

\section{Diskrepansen mellan fysisk och social rörlighet}

I de områdesbytande elevernas motiv framhålls föreställningen om att en "svensk skola" är en skola med kvalitet. Eftersom skolan har bra betygsstatistik och ett gott rykte förväntar sig de områdesbytande eleverna att också själva bli "lyckade" bara av att befinna sig i området och på skolan. Väl på plats i den nya miljön skapas dock sociala spänningar som gör att de områdesbytande eleverna söker sig, precis som eleverna i Ängdalen, till sina vänner från hemområdet som de känner samhörighet med.

Förespråkare för fria skolval (här Friskolornas riksförbund) menar som svar till dem som hävdar att reformen förstärker segregationen (Skolverket 20I2; se också Östh m.fl. 2013) att det först och främst är boendet som är orsaken till detta. Vidare menar de att det är möjligheten till och kunskapen inför att göra aktiva val som är avgörande för segregationen, inte den fristående skolan som form. Bland de områdesbytande eleverna verkar det vid en första anblick som att den fristående skolan Liberum faktiskt har en etnisk mångfald och att skolan lyckats locka såväl innerstadsbor som förortsbor och även elever från närliggande småorter. I intervjuerna framkommer dock att eleverna fortfarande känner 
en annorlundahet som kan vara svår för bara en skola att bryta. De intervjuade elevernas upplevelse av att inte passa in gäller olika aspekter och tar sig skilda uttryck, exempelvis i skolprestationer och pråkbruk. Distansen som eleverna uppger sig känna är kopplad till klass- och boendetillhörigheten, även om det ofta talas om den som beroende av etnisk tillhörighet. Begreppet "blatte" bör därför förstås intersektionellt.

SAIRA: Jag visste redan, "stan", man tänker sig rikemansbarn [skratt], "jag kommer säkert inte få lika många vänner" ... alltså, man känner sig lite ... utanför.

SAMIRA: Att man inte riktigt känner sig som hemma.

SAIRA: Det har att göra med var man bor. Jag har bott i Ängdalen hela mitt liv och när man kommer till skolan alla softar, chillar, kanske inte ens går till lektionerna.

SAMIRA: Hon menar att vi kommer ju alla från Ängdalen, vi kommer från samma kultur, samma religion och här är det liksom annorlunda människor. [...] Du har lättare att lära känna folk i Ängdalen men här är det lite svårare. Men man kan inte dra alla över en kam. I min förra skola var det många svenskar, vi kom jättebra överens. Jag tror det handlar om var man kommer från, skolan innan eller dagis innan.

MAJSA: Hur då?

SAIRA: Du vet, vi är blattar [skratt], vi är mer "bebis" med varandra! [Mina citationstecken. "Bebis" betyder familjära, nära vänner.]

SAMIRA: Svenskar då?

SAIRA: Men svenskar, det finns vissa svenskar som oss men ...

SAMIRA: Ja, och det beror på var de tidigare bott eller bor liksom.

MAJSA: Så det är var man bor?

SAMIRA: Ja, jag tror det.

SAIRA: Alla från Ängdalen, dom är bebis, dom här dom kanske är wannabekompisar [skratt], det är inte riktigt kompisar, inte riktig vänskap utan bara ... "Hej - hej då", det räcker [skratt].

SAMIRA: Nya vänner som man träffat här, det är ingen man gått hem till eller umgåtts med utanför skolan.

SAIRA: Det känns fortfarande som att jag inte riktigt har jättebra kontakt fast jag gått tre år. Det känns som att man inte kan göra bort sig. Framför henne [Samira] kan jag göra vad jag vill men framför dom andra så känner jag mig annorlunda.

Förutom upplevelser av annorlundahet mellan eleverna finns en känsla av distans till lärarna på skolan. På Liberum har de ett mentorssystem som innebär att en lärare har kontakt med samma elever genom hela skolgången. Denna lärare ska även sköta kontakten med föräldrarna om 
något behöver informeras om, en princip som är starkt implementerad på skolan och som lärarna uppger sig vara nöjda med. I intervjun med Yousef och Taymaz kommer lärarnas täta kontakt med föräldrarna snabbt på tal. De menar att lärarna överreagerar på småsaker och ringer hem för ofta, som när de kastat suddgummi eller "låtsastjafsat" med en kompis. Eleverna menar att det förvisso är bra med dialog men att det går till överdrift och att deras upplevelser av annorlundahet förstärks.

YOUSEF: Lärarna, dom tror vi lever sån Svenssonfamilj, dom tror vi sitter och diskuterar och så. Sitter vid ett bord, hela familjen diskuterar. Dom vill att vi ska göra så men ... Nej tack!

MAJSA: Hur går det till i stället då?

YOUSEF: Dom ringer hem, mamma svarar, mamma säger dom ringde, hon frågar vad som hände, jag svarar, hon säger gör inte om det, khalas, klart!

Cindy som gick på Liberum i ett år beskriver sina upplevelser av skolan. Tidigare förklarade hon att hon har "samma balans" som de andra i Ängdalen. Den här gången träder även en etnisk dimension fram.

CINDY: För det första, jag känner alla här, och grejen är att alla är blattar. Där är det bara sån svensk lärare, svensk allt, allt, allt svenskt, så du är invandraren. Men vi var ändå en grupp invandrare som gick med varandra, då kändes det som här [skolan i Ängdalen] ... men här [skolan] är här, man kan inte säga att här [skolan] är där så jag kan inte göra det jag gjorde här ... Vi var en grupp du vet, om en skolkade, skolkade dom andra. Så fick vi alla problem. Men svenskarna dom skolkade också, men ändå vet jag inte hur dom gjorde för att gå ur det där problemet. Vi såg att vi satt i samma problem men ändå så klarade dom sig. $\mathrm{Vi}$ fattade inte men vi brydde oss inte faktiskt.

MAJSA: Vad kan det bero på?

CINDY: Att dom [lärarna] är svenne. Jag ville få [sagt] det där ordet, att dom är rasist men jag tänkte "skitsamma".

MAJSA: Vad fick dig att hämma dig?

CINDY: Alltså jag tänkte att jag är ny, att jag ska vara mer ... vara lugn.

När Cindy säger "Vi fattade men vi brydde oss inte" ger det av hennes ton att döma uttryck för en hopplöshet som övergått till likgiltighet. Hennes tolkning av den ojämlika situationen utgår ifrån etnisk tillhörighet, där lärarna och de "svenska" eleverna enligt henne har en etnisk gemenskap och därför en mer fördelaktig relation till varandra. Samtidigt betonar hon platsen som avgörande för hur man kan bete sig och 
umgås. Förorten och innerstaden får representera platser där etniska relationer yttrar sig. Med beskrivningen "då kändes det som här, men man kan inte säga att här är där" menar Cindy att de kompisar från Ängdalen som gick på Liberum umgicks och formade något liknande en diaspora. Däremot gjorde den nya miljön sig ständigt påmind om att det fortfarande inte var "här", det vill säga Ängdalen.

I sitt tal förhåller sig eleverna till den förenklade och normerande dikotomin svensk-invandrare med en föreställning om "Svensson" som en homogen medelklassgrupp, framför allt på grund av språket och andra kulturella koder. Elevernas resonerande om vad "svensk" innebär varierar beroende på vad som diskuteras, men genomgående handlar det om att befinna sig i ett materiellt och kulturellt överläge. När Cindy beskriver svenskar som att de "tror sig något, tror sig tuff, har alltid rätt" handlar det om en självsäkerhet och självklarhet som svenska ungdomar upplevs kunna röra sig med, ett habitus. Det är ingen essentialistisk beskrivning hon eller någon annan av eleverna använder sig av, utan en som är direkt kopplad till makt och som blir avgörande för hur bra man platsar i det nya området och skolan. Exempel på hur "svenskhet" kan yttra sig är vilket språkbruk man har och hur mycket eget ansvar man förmår ta.

\section{Disidentifikation med symboliskt kapital}

I intervjuerna framgår det hos de områdesbytande eleverna en upplevelse av att befinna sig i ett liminalt stadium (Turner 1995, s. I28), alltså ett slags "mellanförskap" (jfr Kallstenius 20IO, s. I70) där man varken är "svensk", genom att man tillhör den nya miljön, eller "icke-svensk", eftersom man genomgår en ny erfarenhet som inte kan ignoreras. ${ }^{7}$ Eleverna måste därför hitta strategier för att hantera de olika koder och symbolspråk som är gångbara i de olika miljöerna. Vems erkännande, vare sig det kommer från den nya miljön eller från den där man tidigare platsade, som får betydelse kan därför beskrivas som att det avgörs i en

7. Båda begreppen, "liminalitet" och "mellanförskap", kan tyckas synonyma men har något olika ingångar. Det tidigare betonar en process och en riktning medan det senare är mer fast och uttrycker ett varken eller eller ett både och. 
trasslig och ambivalent process, där självuppfattningen och identiteten hamnar i ett läge av omformning och lyhördhet inför nya normer.

Man skulle kunna beskriva denna ambivalenta process som en trögflytande transformering inom en potentiell klassresa, där främst det sociala, kulturella och språkliga kapitalet är i konstant utveckling när individen orienterar sig i nya symboler och värden. I fallet med de intervjuade eleverna beskrivs ett starkt motstånd mot de normer som de samtidigt förväntas sträva efter. Samtliga elever är väl medvetna om stadens etniska och klassmässiga polarisering och de är tvungna att förhålla sig till den genom dess konkreta symboliska uttryck. Genomgående visar det sig att just språket är en sådan central markör, som eleverna på Liberum delvis anpassar sig till men samtidigt gör motstånd mot.

Skillnaderna i språklig kompetens handlar inte bara om ordförråd och grammatikkunskaper. Det handlar om en internalisering, ett varande och ett sätt att framställa sig. Bourdieu menar att man inte kan "tillägna sig ett språk utan att samtidigt tillägna sig ett speciellt förhållande till språket" (Bourdieu \& Passeron 2008, s. I63, originalets kursivering). Inställningen till och hanteringen av språket, menar han, är en av de tydligaste distinktionerna mellan det "bildade" (som karaktäriseras av det objektiva, distanserade, abstrakta och formaliserade) och det "folkliga” (det mer målande, uttrycksfulla, friska och skämtsamma) språkbruket. På så sätt är språket en av de mest effektiva distinktionerna som skolan kan använda sig av på samma gång som det är en av de mest dolda sorteringsprocesserna. Främst handlar det om att behärska formen som skolan kommunicerar inom och inte om innehåll och kunskapskompetens (Bourdieu \& Passeron 2008, s. I20). Yousef som går på Liberum och bor i Ängdalen berättar:

YOUSEF: Vi säger om du råkar säga nåt fel, ordfel, typ om du skulle säga "knuffade" men du skulle råka säga "knuffte", brydde sig ingen i våran gamla skola men här skulle någon rätta dig. MAJSA: Har du blivit rättad? YOUSEF: Tusen gånger. MAJSA: Av elever eller lärare? yousef: Av elever och lärare. 
Jamal, som även han bor i Ängdalen och som gått på Liberum i snart tre år, berättar om sina upplevelser.

JAMAL: Jag använde ganska mycket slangord. För att passa ihop med dom här inne fick jag ändra mig på sätt och vis, prata finare svenska, inte använda slangord. Typ "Sho bro vad gör du?" - "Hej, hur är det?", så fick jag ändra på grund av att vissa inte tyckte det lät så bra.

MAJSA: Vad skulle hända om du skulle säga så?

JAMAL: Dom tänker ju, "Vi pratar inte så, varför gör han det?" Vissa tycker inte att svenska borde användas så där. Det är massa slangord tänker dom. Här i skolan så pratar jag ren svenska men i orten, där har du alla slags slangord.

MAJSA: Är det jobbigt att behöva anpassa sig?

JAMAL: Nej inte alltid, nu är jag van vid det. I början var det ganska svårt, det kom ut slangord då och då. Från ingenstans ändrade dom bara blicken ... [Jag] tänkte "Vad fan sa jag?" [Skratt.]

Det framgår tydligt att eleverna anpassar sig till den nya miljön där de på olika sätt påminns om när de pratar "fel", "ofin" eller "oren" svenska. När Jamal exemplifierar hur han får ändra sitt sätt att prata växlar han snabbt över till en "korrekt" svenska med ett "korrekt" tonfall. Det visar att han liksom de andra eleverna är väl medvetna om hur "bra" svenska bör talas och behärskar den när de vill. Språkbruket bör därför tolkas som en karaktärsdefinition som kan användas strategiskt för att röra sig i olika rum. Det visar också att språket inte är bundet till ett etniskt ursprung, utan att det är platsbundet (jfr Jonsson 2007). Att elever som går i skolan $\mathrm{i}$ innerstaden anpassar sig efter vilken miljö de befinner sig i är något som även eleverna som valt att gå kvar i Ängdalen uppmärksammat.

ABED: Jag märker mycket skillnad, oftast på språket hur personen pratar. Såna som går [i] skolan inne i stan dom har bättre ... dom använder inte lika mycket förortsord så som folk i förorten. Du är ju ändå i skolan från åtta till tre och så kommer du hem och umgås med folk du är med i skolan hela tiden. Du använder ju samma dialekt, eller inte dialekt, hur ska man säga, samma språk. Ifall du går en skola inne i stan pratar dom fint språk eller hur man säger, använder inte mycket svordomar, slang och sånt ... Du lär dig mycket mer ord och så.

MAJSA: Och du Aram, tycker du att det finns en skillnad också?

ARAM: Till exempel dom som går [i] nån svensk skola, när dom är med dom, deras kompisar i skolan, pratar dom med dom på ett visst sätt, när dom är med oss ett annat sätt. 
Vid tanken på att gå på en innerstadsskola framgår språket som en central markör som skulle kunna skapa exkludering.

MAJSA: Om du föreställer dig att du skulle gå där [skola i stan], hur skulle det vara?

MUSTAFA: Jag skulle inte snacka så som jag snackar nu, alltså jag skulle snacka riktig svenska.

MAJSA: Riktig svenska?

MUSTAFA: Alltså, jag skulle inte sagt typ "mannen" och så, slang och så.

MAJSA: Vad skulle hända om du sa "mannen walla jag svär"?

MUSTAFA: Dom skulle inte ta mig på allvar, dom skulle tro det är ett skämt. [...] Om du går runt och säger "walla billa", det är klart folk får fördomar. Dom tror säkert han är kriminell.

Eleverna exemplifierar språkets betydelse genom att återkommande beskriva hur svårt det skulle vara att få en anställning om man använde slang i stället för att prata "ren och fin" svenska. Även om dessa elever inte känner till de exakta siffrorna är exemplet med arbetsintervjun ett reellt scenario och därför en högst befogad oro. Statistiskt sett har ungdomar med invandrarbakgrund 40 procent större risk att hamna i arbetslöshet än etniskt svenska ungdomar (Schierup \& Urban 2007, s. 7I). Om språket i sig har en påverkan på om man får en anställning är svårt att svara på men onekligen är det en laddad kulturell symbol som kan värderas olika och som är klassbetingad (Bernstein 2000). Logiken från elevernas håll blir således att ändra på denna symbol, eftersom den representerar sämre förutsättningar. Det liknar de områdesbytande elevernas resonemang om själva skolbytet.

Samtidigt sker en stark disidentifiering på grund av den överhängande känslan av underordning. Det gör att eleverna, oavsett om det gäller språk, synen på utbildningskvalitet eller bostadsområde, medvetet valt att till stor del återgå till eller uppvärdera praktiker som de menar karaktäriserar förorten (jfr Peterson m.fl. 2003, s. II6). Det kan till exempel vara att söka sig till andra "blattar" och prata det de kallar för "dålig" svenska.

För att helt förstå hur och varför disidentifieringen tar den form den gör måste man också ta hänsyn till de specifika förutsättningar som råder på Liberum. Det faktum att det finns en utpräglad grupp av elever på 
Liberum som bor i Ängdalen skapar möjligheter för en gemenskap och en kollektiv disidentifikation, likt en stärkande diaspora, vilket minskar upplevelsen av utsatthet. Detta gör att skolan, lärarna och de övriga eleverna inte påverkar de enskilda eleverna från Ängdalen lika djupgående som de skulle ha kunnat göra om det rörde sig om enstaka elever. I stället hämtar de enskilda eleverna styrka från kollektivet. Skolan och de områdesbytande eleverna bevarar därför ett avstånd mellan varandra som gör det svårt för skolan att överföra sina normer. Men med den kollektiva vikänslan som uppstår bland eleverna från Ängdalen finns också en risk för att de begränsas i sin sociala rörlighet, på grund av kollektiv förväntan.

Det var dock ingenting som de intervjuade eleverna framhöll som en erfarenhet de personligen haft. Däremot kunde det tydligt markeras om de upplevde att bekanta eftersökte "de andra". Cindy beskriver sina upplevelser:

MAJSA: Finns det nån skillnad på dom elever som bor i Ängdalen men går i stan? CINDY: Jag tror att folket går dit för det mesta för vänner, svenskar.

MAJSA: Svenska vänner?

CINDY: Jag tror det [fnysande skratt].

MAJSA: Varför vill man ha svenska vänner då?

CINDY: Jag vill inte ha svenska vänner! Jag trivs inte ens med svenskar. Jag trivs med blattar.

MAJSA: Varför vill dom ha det då?

CINDY: Man kanske vill passa in i gruppen ... Jag har somaliska kompisar som är helt svensk-, helt svenskaktiga, dom umgås bara med svenskar ... nej nej nej.

MAJSA: Hur är man när man är svenskaktig?

CINDY: Tror sig något, tror sig tuff, ha alltid rätt ...

MAJSA: Nåt mer?

CINDY: Dom klär sig inte som ... Alltså vi som går här i Ängdalen, vi kanske tar på oss mjukis, träningströja ... och om dom ser oss så säger dom "Hallå vi är inte hemma, vad går du ut med?”, förstår du, så. Så umgås dom bara med svenska killar, svenska tjejer. Så om man säger ett blattenamn säger dom "Vad är det där för nåt?”, typ. Dom är vana vid svenska Anna, David, Daniel ... såna namn. När man säger ett blattenamn så säger dom ”Det var udda!" [Ändrar tonfallet till "korrekt" svenska.]

Den starka disidentifiering med "svenskar" som Cindy demonstrerar kan tolkas som en konsekvens av hennes erfarenheter av att känna sig underordnad när hon och hennes "icke-svenska" vänner får ifrågasät- 
tande kommentarer om hur de klär sig eller vad de heter. Detta kan vara en av orsakerna till att, som Mustafa formulerade det, "folk [i Ängdalen] skulle kolla snett" om man pratade "fin" svenska.

\section{Social reproduktion och transformation genom ansvarsförskjutningar}

Studien visar att eleverna som bor i förorten väljer att gå på en fristående skola i innerstaden för att förbättra sina livsvillkor. Skolan tillskrivs egenskaper som "bättre" och "svensk" eftersom den befinner sig på en plats som associeras till svenskhet. Svenskhet bör därför förstås som ett symboliskt kapital som produceras intersektionellt i skärningen mellan etnicitet, klass och de egenskaper platser tillskrivs. På så sätt blir begrepp som "blatte" och "svenne" det som eleverna använder sig av för att beskriva dessa relationer av under- och överordning. På individnivå finns potential för social transformation genom att man tillskansar sig högt värderade symboler och en ny kamrateffekt. Studien visar dock att eleverna i interaktionen med denna "svenska" innerstadsskola blir påminda om att de talar annorlunda, bor på fel plats och är etniskt avvikande i relation till de övriga eleverna och lärarna. Förutom känslan av annorlundahet förmår inte skolan ta hänsyn till elevernas bakgrund och förutsättningar i sina förväntningar på prestation och förmåga till eget ansvar. Eleverna ger därför uttryck för disidentifikation i den nya miljön och vissa väljer till och med att återgå till skolorna i Ängdalen.

Eleverna som valt att gå kvar på de kommunala skolorna i Ängdalen går där på grund av geografisk närhet, vänner och att de menar sig ha jämn prestationsnivå med de övriga eleverna. De uppger sig också känna en avsaknad av hjälp och förståelse, precis som eleverna på Liberum. På så sätt skapas det en oro inför att inte få tillräckligt med kunskap, vilket bygger dels på det rykte förortsskolan har i allmänhet (som bortvalsskola), dels på att eleverna inte upplever att lärarna är tillräckligt engagerade eller förstående. I stället för extra personal får eleverna exempelvis möta olika former av disciplinering.

Båda skolformerna, som står i direkt ekonomisk relation till varandra, misslyckas därför med att tilltala elever som bor i förorten, och i 
stället sker en fortsatt sortering och reproduktion av klass- och etnicitetsrelationer. Mekanismerna utspelar sig både på de kommunala förortskolorna i Ängdalen och på den fristående innerstadsskolan Liberum, dock utifrån skilda ekonomiska motiv. Enligt utbildningsmarknadens logik avgörs inte Liberums existens om eleverna från förorten väljer att gå där eller inte, snarare försämrar de skolans rykte. Samtidigt blir situationen på de kommunala förortsskolorna svårare när de systematiskt blir bortvalda. De strukturella oprivilegierade villkoren som de intervjuade eleverna befinner sig i kombinerat med ett större elevansvar, till följd av utbildningsmarknaden, gör att elevernas underordning förstärks.

Transformationerna av det svenska utbildningssystemet har sedan 1990-talet karaktäriserats av en rad skolreformer som står i värdekonflikt med tidigare utbildningspolitik. Genom att låta privata skattefinansierade och vinstdrivande aktörer stå som huvudmän för skolor avgör konkurrensen om eleverna skolornas resurser, kvalitet och existens, framför allt i storstadsområdena. Att eftersträva nationell likvärdighet skolor emellan framträder som en grundläggande paradox inom nuvarande system. Ball menar att utbildningssystemets utformning negligerar det sociala livets komplexitet och processer genom att omvandla utbildningen till en vara (Ball 2004).

Men det är inte bara verksamheten som kommodifieras, även sociala relationer och roller får nya dimensioner. Förutom den uttalade konkurrensen mellan skolor kan man tolka situationen som att det råder konkurrens mellan eleverna, i en situation där förortseleverna utkonkurreras och utsorteras som ett resultat av den förskjutna ansvarsfrågan villkorad av elevernas klasspositioner. De mer självgående eleverna betraktas som mer eftertraktade eftersom de inte kräver lika mycket resurser, i form av exempelvis hemspråkslärare, medan mer resurskrävande elever ur ett kostnadsperspektiv anses som mindre attraktiva. Effekten av en nedpressad budget är att skolorna söker att rekrytera högpresterande elever, det vill säga de som effektivast tillgodogör sig ämnena och som dessutom attraherar andra (liknande) elever (se Ball 2004, s. Io). Detta har resulterat i att skolan tappat sin likvärdighet och att eleverna hamnar i A- och B-lag, där klyftorna växer mellan dem som klarar kunskapsmålen och dem som får allt sämre resultat (Skolverket 20I2). 
Elever med utländsk bakgrund, bosatta i en stigmatiserad förort, kan känna en alienation i såväl den kommunala som den fristående skolan och med kontrollsystemen tillkommer ytterligare en dimension av annorlundahet som skolan bidrar med. I en skolvardag med betygsdilemman, rädsla för kunskapsbrist, frånvaro av hjälp, kameraövervakning och så vidare blir då den viktigaste faktorn bakom elevernas skolval trivseln och känslan av tillhörighet. Den främsta orsaken till att man väljer att stanna kvar i området (och i sin tur skolan) är att man vill vara nära kompisar. Skolornas oförmåga att möta elevernas behov genererar, enligt eleverna, avsaknad av stöd och erkännande, vilket kan leda till själveliminering.

Elevernas osäkerhet är inte bara ett hinder för att tillgodogöra sig skolämnena, den formar också habitus av hämmande och begränsande karaktär, något som kan tolkas som en konsekvens av skolans symboliska våld och selektering (Bourdieu \& Passeron 2008). Elevernas situation är varken förenlig med visionen om "en skola för alla" eller "ett fritt skolval”. Båda brister i sin hänsyn till elevers bakgrund och förutsättningar i det svenska samhället. Diversifieringen av skolor matchar inte diversifieringen av elever som finns i "det nya Sverige". Med en stark kollektiv känsla av annorlundahet disidentifierar sig förortseleverna med förväntningarna om att vara som "svenska" elever och att göra "rationella" skolval som gynnar dem när de ska komma vidare ut i arbetslivet. I stället lyfter eleverna fram vikten av sociala aspekter, som utbildningspolitiken försummat till bekostnad för fokus på prestation och valfrihet. Detta yttrar sig genom ett värderande av sina egna subjektspositioner och sitt eget hemområde som något mer eftersträvansvärt.

\section{Referenser}

Alvesson, Mats \& Sköldberg, Kaj (2008) Tolkning och reflektion. Vetenskapsfilosofi och kvalitativ metod. Lund: Studentlitteratur.

Archer, Margret S. (2007) Making our way through the world. Human reflexivity and social mobility. Cambridge: Cambridge University Press.

Ball, Stephen J. (2004) Education for sale! The commodification of everything? King's Annual Education Lecture. Institute of Education, University of London. URL: http://nepc.colorado.edu/files/CERU-04IO-253-OWI.pdf (2 oktober 2015)

Ball, Stephen J. (2006) Education policy and social class. The selected works of Stephen J. Ball. London: Routledge. 
Bernstein, Basil (2000) Pedagogy, symbolic control and identity. Theory, research, critique. Lanham: Roman \& Littlefield.

Bourdieu, Pierre (2004) Praktiskt förnuft. Bidrag till en handlingsteori. Göteborg: Daidalos.

Bourdieu, Pierre \& Passeron, Jean-Claude (2008) Reproduktionen. Bidrag till en teori om utbildningssystemet. Lund: Arkiv förlag.

Bunar, Nihad (2005) "Valfrihet och anti-segregerande åtgärder. När skolpolitik och integrationspolitik möts i det socialt, etniskt och symboliskt polariserade urbana rummet”, Utbildning \& Demokrati, vol. I4, nr 3, s. 75-96.

URL: http://www.oru.se/Extern/Forskning/Forskningsmiljoer/HumUS/Utbildning_ och_Demokrati/Tidskriften/2005/Nr\%203_2005_pdf/Bunar.pdf (2 oktober 2015)

Bunar, Nihad (2009) När marknaden kom till förorten. Valfrihet, konkurrens och symboliskt kapital i mångkulturella områdens skolor. Lund: Studentlitteratur.

Bunar, Nihad \& Kallstenius, Jenny (2008) Valfrihet, integration och segregation $i$ Stockholms grundskolor. 2. uppl. Stockholm: Utbildningsförvaltningen, Stockholms stad.

Dahlstedt, Magnus (2007) "I val(o)frihetens spår. Segregation, differentiering och två decennier av skolreformer", Pedagogisk forskning $i$ Sverige, vol. I2, nr I, s. 20-38. URL: http://journals.lub.lu.se/index.php/pfs/article/view/773I (2 oktober 2015)

Dikeç, Mustafa (2007) Badlands of the republic. Space, politics, and urban policy. Oxford: Blackwell.

Dovemark, Marianne (2004) Ansvar - flexibilitet - valfrihet. En etnografisk studie om en skola i förändring. Avhandling. Göteborg: Göteborgs universitet.

Englund, Tomas (1993) Utbildning som "public good" eller "private good". Svensk skola $i$ omvandling? Uppsala: Pedagogiska institutionen, Uppsala universitet.

Englund, Tomas (red.) (I995) Utbildningspolitiskt systemskifte? Stockholm: HLS förlag.

Franzén, Mats (200I) "Problemet segregation. En orättvis jämförelse”, i Magnusson Turner, Lena (red.) Den delade staden. Segregation och etnicitet $i$ stadsbygden. Umeå: Boréa.

Fredriksson, Anders (20I0) Marknaden och lärarna. Hur organiseringen av skolan påverkar lärares offentliga tjänstemannaskap. Göteborg: Statsvetenskapliga institutionen, Göteborgs universitet.

Gilroy, Paul (198I) "You can't fool the youths ... race and class formation in the I980s", Race \& Class, vol. 23, $\mathrm{nr} 2-3$, s. 207-222. DOI: http://dx.doi.org/Io.1177/030639688102300206

Harvey, David (20II) Ojämlikhetens nya geografi. Texter om stadens och rummets förändringar i den globala kapitalismen. Stockholm: Atlas.

Härnqvist, Kjell (1994) "Social selektion till gymnasium och högskola”, i Erikson, Robert \& Jonsson, Jan O. (red.) Sorteringen i skolan. Studier av snedrekrytering och utbildningens konsekvenser. Stockholm: Carlssons.

Jonsson, Rickard (2007) Blatte betyder kompis. Om maskulinitet och språk i en högstadieskola. Avhandling. Stockholm: Ordfront.

Kallstenius, Jenny (2010) De mångkulturella innerstadsskolorna. Om skolval, segregation och utbildningsstrategier $i$ Stockholm. Avhandling. Stockholm: Sociologiska institutionen, Stockholms universitet. 
Kvale, Steinar \& Brinkmann, Sven (2009) Den kvalitativa forskningsintervjun. Lund: Studentlitteratur.

Liedman, Sven-Eric (20II) Hets! En bok om skolan. Stockholm: Albert Bonniers Förlag.

Magnusson Turner, Lena (red.) (200I) Den delade staden. Segregation och etnicitet i stadsbygden. Umeå: Boréa.

Molina, Irene (1997) Stadens rasifiering. Etnisk boendesegregation i folkhemmet. Avhandling. Uppsala: Kulturgeografiska institutionen, Uppsala universitet.

Peterson, Abby m.fl. (2003) Ungdomar i vardagens väv. En sociologisk studie av ungdomars gruppbildande i en storstadsförort. Lund: Studentlitteratur.

Proposition 1982/83:I. Regeringens proposition om skolor med enskild huvudman.

Quennerstedt, Ann (2012) "Kommunens ansvar och inflytande på skolområdet", i Jarl, Maria \& Pierre, Jon (red.) Skolan som politisk organisation. Malmö: Gleerups.

Runfors, Ann (2003) Mångfald, motsägelser och marginaliseringar. En studie av hur invandrarskap formas i skolan. Stockholm: Prisma.

Schierup, Carl-Ulrik \& Urban, Susanne (2007) "Social exkludering. Ett beskuret medborgarskap", i Dahlstedt, Magnus m.fl. (red.) Utbildning, arbete, medborgarskap. Strategier för social inkludering $i$ den mångetniska staden. Umeå: Boréa.

Sernhede, Ove (2006) "Förortens 'hotfulla' unga män. Andrafieringens geografi och behovet av alternativ till stigmatisering och kriminalisering", i Kamali, Masoud (red.) Den segregerande integrationen. Om social sammanhallning och dess hinder. SOU 2006:73. Stockholm: Fritzes.

Sernhede, Ove (2007) Alienation is my nation. Hiphop och unga mäns utanförskap $i$ Det nya Sverige. Stockholm: Ordfront.

Sernhede, Ove (red.) (20II) Förorten, skolan och ungdomskulturen. Reproduktionen av marginalitet och ungas informella lärande. Göteborg: Daidalos.

SFS 20I0:80o. Skollag.

Skeggs, Beverley (1997) Formations of class and gender. Becoming respectable. London: Sage (sv. övers. 2000, Att bli respektabel. Konstruktioner av klass och kön. Göteborg: Daidalos).

Skolverket (1996) Att välja skola. Effekter av valmöjligheter i grundskolan. Stockholm.

Skolverket (2003) Valfrihet och dess effekter inom skolområdet. En sammanfattning. Stockholm.

Skolverket (2005) Skolor som alla andra? Med fristaiende skolor i systemet 199I-2004. Stockholm.

URL: http://www.skolverket.se/publikationer?id=I537 ( 2 oktober 20I5)

Skolverket (20IIa) "Barn och elever med utländsk bakgrund", i Skolverkets lägesbedömning 20II. Del I, Beskrivande data. Förskoleverksambet, skolbarnsomsorg, skola och vuxenutbildning. Stockholm.

Skolverket (20IIb) Elever i grundskolan läsåret 20Io/II. PM. Stockholm. URL: http://www.skolverket.se/publikationer?id=2518 ( 2 oktober 2015)

Skolverket (2012) Likvärdig utbildning i svensk skola? En kvantitativ analys av likvärdighet över tid. Stockholm.

Smith, Susan J. (1989) The politics of "race" and residence. Citizenship, segregation and white supremacy in Britain. Cambridge: Polity. 
ARKIV $\mid$ NR 4

Turner, Victor (1995) The ritual process. Structure and anti-structure. New York: Aldine de Gruyter.

Ungdomsstyrelsen (2008) Fokus 08. En analys av ungas utanförskap. Stockholm.

Wacquant, Loïc (2009) Punishing the poor. The neoliberal government of social insecurity. Durham: Duke University Press.

Ålund, Aleksandra (1997) Multikultiungdom. Kön, etnicitet, identitet. Lund: Studentlitteratur.

Östh, John m.fl. (2013) "School choice and increasing performance difference. A counterfactual approach", Urban Studies, vol. 50, nr 2, s. 407-425.

DOI: http://dx.doi.org/IO.II77/00420980I2452322 


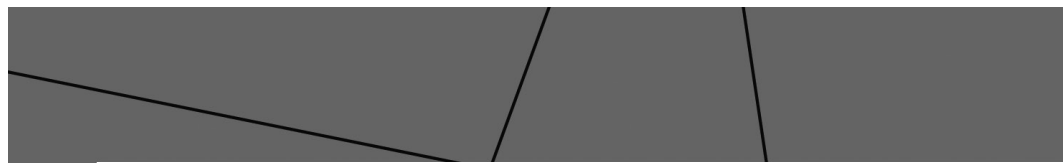

\section{VALFRI VÄLFÄRD}

Ett medborgarperspektiv på den svenska välfärdsstaten

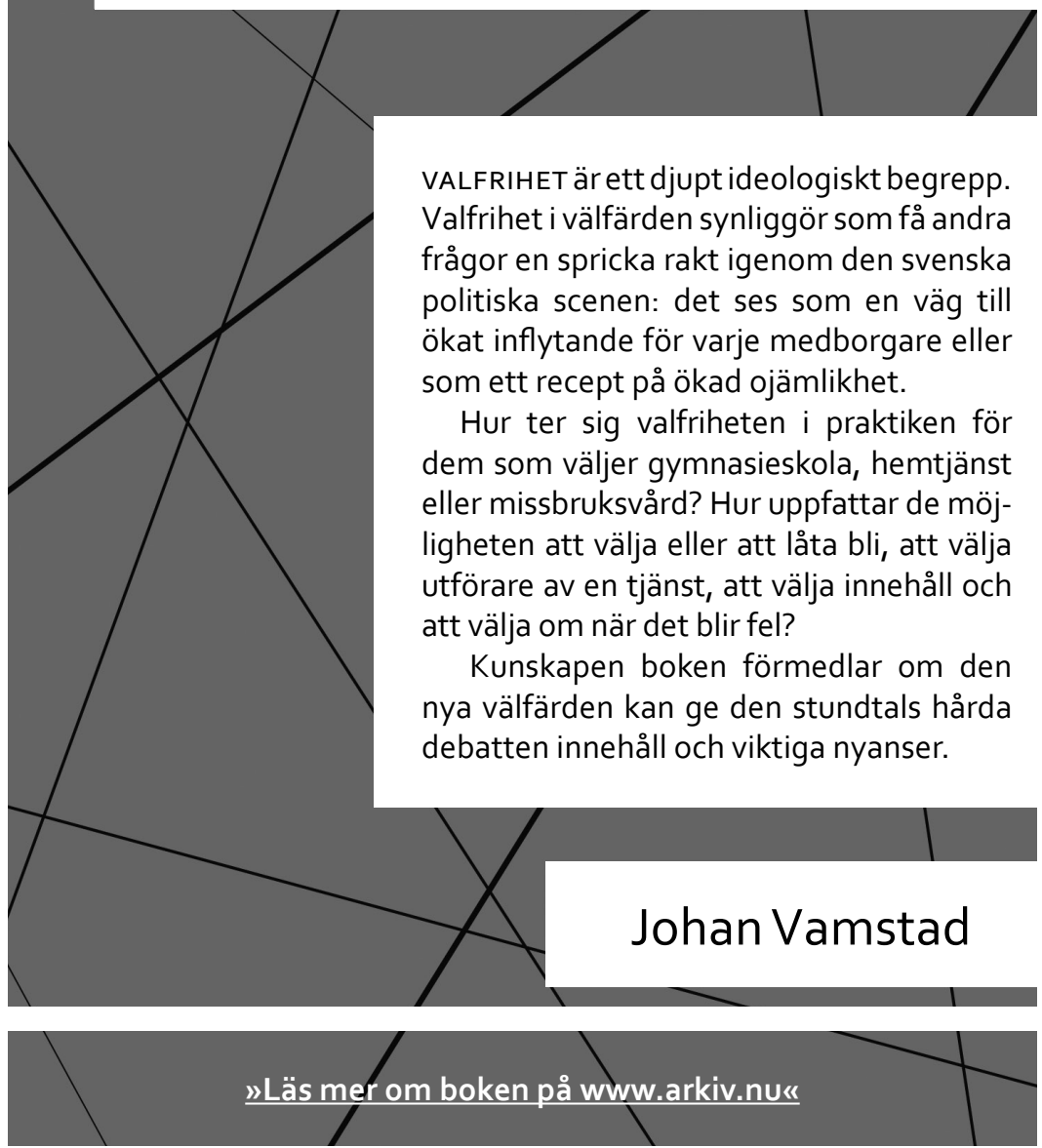




\section{Moderna klassiker}

\section{Pierre Bourdieu}

Jean-Claude Passeron

Reproduktionen

\section{Arkiv förlag}

I Reproduktionen. Bidrag till en teori om utbildningssystemet (La reproduction) visar Pierre Bourdieu och Jean-Claude Passeron varför skolsystemet och den högre utbildningen reproducerar ojämlikhet och sociala hierarkier - och hur det sker. Utifrån ett stort empiriskt material formulerar de en allmän teori om utbildning och fostran och i förlängningen en kraftfull teori om klassamhällets och kulturens reproduktion. I ett klargörande förord presenterar Donald Broady bakgrunden till och mottagandet av denna klassiker som sedan den gavs ut 1970 blivit en av de mest inflytelserika och mest citerade sociologiska texterna.

Översättning Gunnar Sandin Arkiv förlag 2008, 296 sidor 